\title{
Kewajiban Dan Tanggung Jawab Notaris Sebagai Pejabat Umum
}

\author{
Abdullah Dian Triwahyuni ${ }^{1}$ \\ ${ }^{1}$ Fakultas Hukum Universitas Udayana, E-mail: garismerah33@gmail.com
}

\begin{tabular}{l}
\hline Info Artikel \\
\hline Masuk : 31 Januari 2020 \\
Diterima : 27 April 2020 \\
Terbit : 30 April 2020 \\
Keywords : \\
Notary; General official; \\
Morality; Governance \\
\\
Kata kunci: Notaris; Pejabat \\
umum; Moralitas; Tata kelola \\
Porresponding Author: \\
garismerah33@gmail.com \\
DOI : \\
10.24843/AC.2020.v05.i01.p01 \\
\end{tabular}

\begin{abstract}
The position of notary has been regulated in Act Number 2 of 2014 concerning Amendment to Law Number 30 of 2004 concerning Notary Position (hereinafter referred to as UUJN-P). Even so, philosophical and technical notary obligations and responsibilities are not regulated in detail in these laws and regulations, leading to the absence of a barometer that becomes a standard for notary behavior, notary office administration system, and notary office governance that applies universally. This has caused in some instances negative views on the notary profession in the community. One of the negative views is because the morality of the notary is not in tune with ethical behavior in society. Negative views also arise due to the administration of notary office administration and the layout of the notary office that does not meet the aesthetic element. The situation made the notary public seem unprofessional in providing social services in his function as a public official. Then what should be the notary morality? How about a good notary office administration? How should the notary manage his office? The writing of this article uses normative research using a positive legal approach and a conceptual approach. Sources of legal materials used are primary legal materials and secondary legal materials. Legal materials were analyzed using descriptive techniques. The results of this study indicate that there are not yet detailed and universal rules regarding the obligations and responsibilities of notaries sociologically and technically in providing social services, but the values that live and develop in society can be used as benchmarks for notary behavior and administrative systems notary office and notary office governance.
\end{abstract}

\begin{tabular}{l} 
Abstrak \\
\hline Jabatan notaris telah diatur dalam Undang-Undang Nomor 2 \\
Tahun 2014 tentang Perubahan Atas Undang-Undang Nomor 30 \\
Tahun 2004 tentang Jabatan Notaris (selanjutnya disebut UUJN- \\
P). Meskipun demikian, ketentuan mengenai kewajiban dan \\
tanggung jawab notaris secara filosofis dan teknis tidak diatur \\
secara terperinci di dalam peraturan perundang-undangan \\
tersebut sehingga menyebabkan ketiadaan barometer yang \\
menjadi standar perilaku notaris, sistem administrasi kantor \\
notaris, dan tata kelola kantor notaris yang berlaku secara \\
universal. Hal ini menyebabkan dalam beberapa kejadian timbul \\
pandangan negatif terhadap profesi notaris di masyarakat. Salah \\
satu dari pandangan negatif tersebut karena moralitas notaris \\
yang di nilai tidak seirama dengan perilaku etis di masyarakat.
\end{tabular}




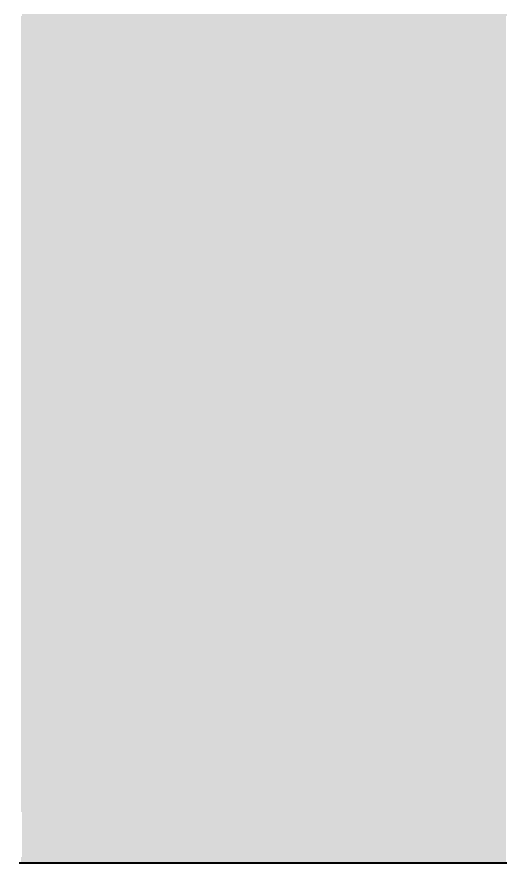

Pandangan negatif juga timbul dikarenakan pengelolaaan administrasi kantor notaris dan tata letak kantor notaris yang kurang memenuhi unsur estetis. Keadaan tersebut membuat notaris terkesan tidak profesional dalam memberikan pelayanan sosial dalam fungsinya sebagai pejabat umum. Lantas bagaimana seharusnya moralitas notaris? Bagaimana administrasi kantor notaris yang baik? Bagaimana seharusnya notaris dalam mengelola kantornya? Penulisan artikel ini menggunakan penelitian secaara normatif dengan menggunakan pendekatan hukum positif dan pendekatan secara konseptual. Sumber bahan hukum yang digunakan adalah bahan hukum primer dan bahan hukum sekunder. Bahan hukum dianalisis menggunakan teknik deskriptif. Hasil dari penelitian ini menunjukkan bahwa memang belum ada aturan yang terperinci dan bersifat universal mengenai kewajiban dan tanggung jawab notaris secara sosiologis dan teknis dalam memberikan pelayanan sosial, namun nilai-nilai yang hidup dan berkembang di masyarakat bisa digunakan sebagai tolak ukur perilaku notaris dan sistem administrasi kantor notaris serta tata kelola kantor notaris.

\section{Pendahuluan}

Notaris adalah bentuk dari pejabat umum. Kedudukan notaris sebagai pejabat umum sesungguhnya bersumber dari negara dan masyarakat. ${ }^{1} \mathrm{Hal}$ ini sebagaimana telah dimuat dalam Pasal 1 angka 1 UUJN-P yang menyatakan bahwa "Notaris adalah pejabat umum yang berwenang untuk membuat akta autentik dan memiliki kewenangan lainnya sebagaimana dimaksud dalam Undang-Undang ini atau berdasarkan undang-undang lainnya.". Isi dalam Pasal ini menyatakan mengenai apa itu notaris. Menurut Pasal ini, notaris ialah seorang pejabat umum yang secara spesifik memiliki kewenangan untuk pembuatan akta-akta yang sifatnya autentik serta kewenangan-kewenangan lainya yang tentu sudah ditentukan di dalam UUJN-P atau juga undang-undang yang lainnya.

Dari ketentuan tersebut, tentu mampu dikembangkan lagi bahwasanya fungsi pejabat umum yaitu notaris mempunyai kewenangan membuat sesuatu yang disebut akta autentik yang memiliki ketersinggungan terhadap segala perbuatan, segala perikatan, perjanjian, dan segala ketetapan dan kesemuanya itu telah ditetapkan dalam hukum positif. Penjelasan terhadap akta autentik sendiri telah dimuat dalam Pasal 1868 Kitab Undang-Undang Hukum Perdata (selanjutnya disebut KUHPer) yang mendeskripsikan akta autentik merupakan akta yang pembentukannya telah ditentukan oleh peraturan perundang-undangan, serta akta tersebut dibuat oleh dan juga bisa di hadapan para pegawai umum yang tentu memiliki kekuasaan dalam hal tersebut di tempat dimana akta tersebut dibuat. ${ }^{2}$ Kewenangan lain yang dimiliki notaris ialah pengesahan suatu tanda tangan serta penetapan waktu termasuk tanggal, bulan, dan tahun suatu surat yang dibuat di bawah tangan dengan menulisnya di buku tertentu

\footnotetext{
${ }^{1}$ Wibawa, P. G. S., Windari, R. A., Sudiatmaka, K., \& Si, M. (2019). PERLINDUNGAN HUKUM BAGI NOTARIS TERHADAP PEMANGGILAN NOTARIS OLEH PENEGAK HUKUM DALAM PROSES PRADILAN DI TINJAU DARI KETENTUAN PASAL 66 UNDANGUNDANG NOMOR 2 TAHUN 2014. Jurnal Komunitas Yustisia, 2(1).

2 Dinaryanti, A. R. (2013). Tinjauan Yuridis Legalisasi Akta Di Bawah Tangan Oleh Notaris. Legal Opinion, 1(3).
} 
serta mengumpulkan dan menjadikannya sebuah buku atas surat-surat yang pembuatannya dilakukan di bawah tangan. Surat di bawah tangan yang menjadi bagian dari akta di bawah tangan itu sendiri deskripsinya telah dimuat dalam Pasal 1874 KUHPer yang artinya ialah suatu bentuk akta yang secara formil maupun materiil yang ditanda tangani secara bawah tangan (tidak di hadapan pejabat umum yang berwenang) serta juga di dalamnya memuat surat, daftar, surat urusan rumah tangga, serta tulisantulisan yang lain yang pembuatannya tidak dilakukan melalui pejabat umum sebagai perantarannya. ${ }^{3}$ Selain itu, kewenangan notaris ialah membuat salinan (copy) dari berbagai dokumen resmi dan/atau asli yang dibuat secara "bawah tangan" yaitu suatu salianan (copy) yang berisi uraian-uraian yang ditulis dan/atau didiskripsikan dalam surat tersebut serta melakukan pengesahan, validasi, dan membuat salinan sama atau fotocopy dengan surat aslinya.

Upaya preventif yang dapat dilakukan oleh notaris sebagai pejabat umum agar tidak terjadi konflik dan kesalah pahaman yang mungkin saja bisa terjadi di kemudian hari ialah salah satunya melaksanakan kewenangannya sesuai dengan sistem sebagaimana yang sudah ditentukan dalam UUJN-P. Berkenaan dengan profesi notaris, untuk menjalankan kewenangannya, secara yuridis atau dalam hukum positif telah diatur dalam UUJN-P. UUJN-P yang merupakan hukum positif tersebut, telah menentukan mengenai apa saja kewajiban-kewajiban notaris, berbagai tanggung jawab notaris, dan apa saja yang menjadi larangan atau pantangan seseorang dalam kedudukanya yang berprofesi sebagai notaris. Jika bicara mengenai hal-hal apa saja sekiranya yang bersinggungan dengan kewajiban-kewajiban seorang yang berprofesi sebagai notaris, kesemuanya itu dengan sangat jelas dan terang telah dimuat di Pasal 16 UUJN-P, sedangkan jika bicara menggenai pertanggung jawaban sebagai wujud dari pejabat umum, telah dimuat di Pasal 65 UUJN-P.

Dari penjabaran di atas, tentu secara yuridis sudah cukup jelas dan terang mengenai apa saja kewajiban dan tanggung jawab serta juga larangan-larangan terhadap profesi notaris. Faktor-faktor lain seperti faktor filosofis dan faktor teknis dari pelaksanaan ketentuan yuridis tersebut juga tidak kalah penting seperti di antaranya ialah moralitas dan sistem administrasi serta kondisi tata kelola kantor yang sangat berpengaruh terhadap kualitas pelayanan notaris. Moralitas itu sendiri dapat diterjemahkan yang maksudnya seperti segala perbuatan yang sifatnya baik atau sifatnya buruk serta perbuatan yang sifatnya benar mapun yang sifatnya salah yang yang kesemuanya merupakan wujud dari asas-asas dan nilai-nilai dalam kehidupan manusia. ${ }^{4}$ Hal lainnya seperti keadaan rapi dan teraturnya administrasi serta baiknya penataan ruangan-ruangan di kantor notaris juga menjadi hal yang cukup penting. Kualitas pelayanan menjadi perhatian khusus bilamana notaris dalam menjalankan kewenangannya bertindak dianggap kurang profesional. Pelayanan secara filosofis dan teknis seperti moralitas dan kondisi tata keloala ruang kantor menjadi prioritas utama yang sekiranya harus diperbaiki demi tercapainya optimalisasi profesi notaris sebagai fungsi dari pejabat umum guna memberikan pelayanan sosial di masyarakat. Penulisan secara normatif dalam jurnal ini dengan menggunakan pendekatan hukum positif (statatute approach) dan pendekatan konseptual (conceptual approach) diharapkan mampu memberikan suatu kontribusi terhadap profesi notaris. Keberadaan suatu tolak ukur atau barometer baru mengenai perilaku yang baik dan benar oleh seorang notaris serta

\footnotetext{
3 Hayatdian, H. D. (2013). Kajian Hukum Surat Kuasa Dibawah Tangan Sebagai Dasar Pembuatan Akta Jaminan Fidusia. Jurnal Hukum Unsrat, 1(1), 120-135.

${ }_{4}$ Bertens, K. (2002). Etika. Jakarta: PT. Gramedia Pustaka Utama. h. 7.
} 
tata kelola kantor notaris yang baik yang memenuhi unsur-unsur estetis yang hidup di masyarakat menjadi hal yang layak untuk dikaji guna tercapainya cita-cita yang luhur dari profesi notaris itu sendiri.

\section{Metode Penulisan}

Penelitian adalah suatu aktivitas ilmiah yang menjadi bagian dari proses pengembangan ilmu pengetahuan dan juga upaya pencerdasan umat manusia. ${ }^{5}$ Pada hakikatnya, penelitian itu seperti yang penulis definisikan dari jurnal ilmiah karya Z. Barus, penelitian merupakan bentuk dari suatu kegiatan yang sifatnya ilmiah yang kesemuanya memiliki tujuan untuk penemuan, pengembangan, dan pengajuan suatu kebenaran yang diyakini sebelumnya agar lebih mantap lagi. Hal ini dikarenakan hanya kebenaranlah yang senantiasa memuaskan hati nurani mansuia. ${ }^{6}$ Sedangkan menurut seorang pakar hukum dari Indonesia, beliau bernama Soerjono Soekanto, penelitian adalah salah satu bentuk kegiatan ilmiah yang kesemuanya didasarkan pada suatu analisis dan susunan yang pengerjaanya tentu dilakukan dengan cara sistematis, metodologis, dan berkesinambungan dan tujuan dari semua itu yaitu untuk mengungkap kebenaran yang tidak lain merupakan salah satu dari manifestasi atau perwujudan keinginan hati nurani manusia agar manusia tersebut lebih tahu lagi tentang segala sesuatu yang sedang di hadapinya. ${ }^{7}$ Berdasarkan uraian ini, terang sudah apa itu yang dimaksud dengan penelitian hukum. Metode penelitian hukum secara normatiflah yang berperan dalam penulisan jurnal ini. Pakar hukum dari Indonesia yang bernama Soerjono Soekanto dan Sri Mamuji, beliau berdua dalam bukunya yang di definisikan oleh penulis menerangkan bahwa metode penelitian hukum normatif atau dalam istilah lain dapat juga disebut sebagai metode penelitian hukum kepustakaan ialah metode atau tata cara yang secara fungsinya merupakan metode yang menggunakan bahan-bahan dari perpustakaan yang digunakan sebagai bahan penelitian. ${ }^{8}$ Dalam metode penelitian hukum secara normatif, pertama-tama yang harus dilakukan ialah meneliti demi menemukan hukum positif atau hukum yang berlaku kini, ditambah juga dengan studi kepustakaan dari berbagai macam buku, jurnal, atau juga pernyataan-pernyataan dari para ahli serta literatur-literatur yang mungkin ada dan kemudian setelah mendapatkan itu semua, maka dikaitkanlah dengan isu-siu hukum yang terjadi di masyarakat sehingga mendapatkan kesimpulan terhadap hak dan kewajiban berdasarkan hukum secara subyektif. ${ }^{9}$

Pendekatan-pendekatan yang seringkali digunakan untuk penelitian hukum yang dapat digunakan diantaranya ialah: pendekatan ketentuan hukum positif (statatute approach), pendekatan fakta-fakta di lapangan (case approach), dan pendekatan yang berlandaskan masa lampau (historical approach), serta pendekatan konseptual (conceptual approach). Dalam penulisan jurnal ini, pendekatan yang digunakan ialah pendekatan ketentuan hukum positif (statute approach) dan pendekatan secara konseptual (conceptual

\footnotetext{
${ }^{5}$ Laurensius Arliman, S. (2018). Peranan Metodologi Penelitian Hukum di Dalam Perkembangan Ilmu Hukum di Indonesia. Jurnal Soumatera Law Review, 1(1).

${ }^{6}$ Barus, Z. (2013). Analisis Filosofis Tentang Peta Konseptual Penelitian Hukum Normatif dan Penelitian Hukum Sosiologis. Jurnal Dinamika Hukum, 13(2), 307-318.

7 Soekanto, S., \& Mamuji, S. (2009). Penelitian Hukum Normatif Suatu Tinjauan Singkat. Jakarta: PT. Raja Grafindo Persada. h. 13.

${ }^{8}$ Ibid. h. 13-14.

9 Rusli, H. (2006). "Metode Penelitian Hukum Normatif: Bagaimana?". Tanggerang: Law Review Fakultas Hukum Universitas Pelita Harapan, Volume V No. 3 Tahun 2006, h. 50.
} 
approach). $\cdot^{10}$ Pendekatan hukum positif (statute approach) dilakukan dengan menemukan undang-undang dan regulasi yang ada, kemudian menelaah mana saja yang memiliki ketersinggungan dengan dunia Kenotariatan, sedangkan pendekatan konseptual (conceptual approach) berupaya mencari dan menelaah konsep-konsep yang relevan yang berkaitan dengan dunia kenotariatan.

\section{Hasil Dan Pembahasan}

\subsection{Moralitas Notaris}

Seringkali kita mendengar istilah etika, etis, dan moral di masyarakat. Istilah etika dan moral adalah istilah yang kesehariannya bersinggungan dengan kehidupan di masyarakat. Etika sendiri ialah salah satu cabang dari filsafat dan filsafat juga merupakan suatu perwujudan terhadap jalan hidup manusia. Filsafat sendiri sebagai perwujudan jalan hidup manusia memiliki tugas untuk meneliti dan menentukan apa saja yang merupakan fakta konkrit sampai pada dasarnya yang paling mendalam. ${ }^{11}$

Etika sendiri adalah suatu pola nilai dan barometer moralitas yang menjadi pedoman untuk kelompok atupun individu guna mengatur tingkah lakunya. Etika memang sering dihubung-hubungkan dengan moralitas seseorang, meskipun demikian etika tentu tidak langsung membuat seseorang tersebut menjadi baik, melainkan etika merupakan alat untuk menemukan suatu aklimasi yang bersifat kritis untuk berhadapan dengan bermacam-macam moralitas yang terkesan membimbangkan. ${ }^{12}$ Moral dan etika sebenarnya adalah perpaduan dari dua frase yang sejiwa, keduanya meiliki hubungan dengan hak dan kewajiban mengenai akhlak terhadap perbuatan yang baik dan buruk yang kemudian terbentuklah kemampuan mental yang menjadikan orang merasa bersemangat, bergairah, selalu berani, memiliki kedisiplinan, dan berintegritas dengan standar kebenaran ketika ia melaksanakan perannya dalam menentukan standar kepatutan dan pengendalian pada kehidupan dan pergaulannya di masyarakat. ${ }^{13}$ Orang sanggup memiliki moral positif serta kepribadiannya yang sesuai dengan etika moral yang berlaku di lingkungan dimana ia hidup merupakan tujuan yang sebenarnya dari etika. Sejatinya teori nilai ialah tentang hakikat perbuatan yang sifatnya buruk ataupun yang sifatnya baik juga perbuatan yang sifatnya salah atau yang sifatnya benar baik secara formil maupun materiil yang mampu dimunculkan dengan hadirnya etika moral dalam kehidupan. Sedangkan adanya istilah etika profesi hukum bersinggungan erat dengan susila manusia, yang mengajarkan mengenai perbuatan yang sifatnya benar atau yang sifatnya salah, tentang perbuatan yang bersifat buruk juga perbuatan yang sifatnya baik, yang memang masuk kedalam kepantasan ataupun yang memang tidak pantas yang dilakukan oleh orang dalam kedudukannya sebagai orang yang melaksanakan kewenangannya termasuk di dalamnya seorang yang berprofesi sebagai notaris yang merupakan pejabat umum. Pakar hukum dari Indonesia yang bernama Notohamidjojo mengemukakan bahwa dalam melaksanakan kewajibannya serta rasa tanggung jawabnya, notaris perlu memiliki sikap yang manusiawi yang artinya adalah bersikap seperti memandang bahwa hukum itu tidak hanya dari segi formalitas saja namun tentu juga dari kebenaran sejati yang sesuai

${ }^{10}$ Marzuki, P. M. (2009). Penelitian Hukum. Jakarta: Kencana Prenada Media Group. h. 93.

${ }^{11}$ Muchsin. (2004). Ikhtisar Materi Pokok Filsafat Hukum. Jakarta: STIH ‘IBLAM’'. h. 66.

12 Yuhertiana, I. (2016). Etika, Organisasi dan Kepatuhan Wajib Pajak. Jurnal Akuntansi Multiparadigma, 7(1), 131-141.

13 Jumiati, I. E. (2012). Dimensi etika dalam pelayanan publik: arti penting, dilema dan implikasinya bagi pelayanan publik di Indonesia. Jurnal Administrasi Publik, 3(1), 32-43. 
dengan hati nurani. Selain itu, notaris perlu memiliki sikap adil yang menjadi standar dalam kehidupan banyak orang. Sedangkan sikap pantas sendiri merupakan pertimbangan berdasarkan hati nurani demi mencapai suatu keadilan dalam suatu perkara yang material serta bersikap jujur yang artinya menyatakan sesuatu itu apa adanya, tidak dibuat-buat, mengada-ada atau sering disebut ngawur. ${ }^{14}$

Jika ditinjau dari segi filosofis, sebenarnya perilaku etis seorang notaris, banyak sekali tolak ukur yang dapat digunakan untuk menentukan suatu ukuran tersebut. Semua ini terjadi dikarenakan belum adanya suatu ukuran yang pas dan berlaku secara menyeluruh di seluruh dunia ini. ${ }^{15}$ Meskipun demikian, tolak ukur-tolak ukur tersebut kini sudah bisa terurai ke dalam suatu prinsip-prinsip dan/atau kelayakan-kelayakan yang penerapannya dan keberlakuannya dapat dilaksankan pada suatu tempat. Sebenarnya dalam susunan yang lebih konkrit maupun kekinian, dapat disimpulkan bahwa barometer untuk tolak ukur nilai terhadap tingkah laku yang siftnya etis terhadap notaris itu dapat pula disebut kode etik notaris. ${ }^{16}$ Menurut pakar hukum dari Indonesia yang bernama Franz Magnis Suseno, beliau berpendapat bahwasanya etika dalam profesi yang luhur ialah keutamaan klien juga pentahbisan yang luhur terhadap tuntutan profesi menjadi prioritas utama. ${ }^{17}$ Pada hakikatnya perilaku baik oleh notaris sanggup dilahirkan jika mendasarkan kepada kode etik notaris. Kode etik notaris memiliki kapasitas untuk mengatur tentang perilaku-perilaku apa saja yang mesti diperbuat dan perilaku-perilaku apa saja yang mesti tidak diperbuat terhadap jabatan umum yang dipegang oleh notaris.

UUJN-P khususnya Pasal 83 ayat (1) menyatakan organisasi notaris menetapkan dan menegakkan kode etik notaris. Pasal 83 ayat (1) UUJN-P ini telah melahirkan perkumpulan notaris secara nasional yang namanya Ikatan Notaris Indonesia (selanjutnya disebut I.N.I) dan dalam perjalannya telah mengadakan kongres luar biasa yang diselenggarakan di Bandung pada tanggal 27 Januari 2015. Dari hasil kongres terebut, telah ditetapkannya suatu kode etik notaris. Kode etik notaris ini telah dimuat dalam anggaran dasar khususnya pada Pasal 13 anggaran dasar (A.D).

Tidak dapat dipungkiri bahwasanya seorang notaris dan klien itu memiki hubungan yang sifatnya pribadi. Hubungan yang bersifat pribadi ini maksudnya ialah adanya hubungan dua atau lebih subyek yang saling mendukung nilai, oleh karena hal tersebut maka secara pribadi, notaris tentu dan jelas bertanggung jawab seutuhnya terhadap mutu jasa-jasa dan pelayanan yang ia berikan. Jika ditinjau dari sudut pandang formal yuridis, memang tidak dapat dipungkiri bahwasanya kedudukan notaris dan klien itu sama dan setara. Sedangkan dari sudut pandang sosio psikologis, hubungan antara notaris dan klien itu tidak setara. Hal itu bisa terjadi karena secara umum adanya ketidakmampuan serta kewenangan klien untuk memberikan penilaian yang sifatnya obyektif terhadap pelayanan yang diberikan oleh notaris dalam tugas profesinya. Sehingga dapat ditarik suatu kesimpulan bahwasanya kepercayaan merupakan modal utama hubungan antara notaris dan klien secara horizontal. Maka dari itu, dalam menjalankan kewenangannya seorang notaris memiliki keharusan agar benar-benar beresensi dengan perilaku yang bernilai positif yang juga sering disebut etika profesi.

\footnotetext{
14 Supriyanta. (2013). Kajian Filosofis Terhadap Standar Perilaku Notaris. Jurnal Yustisia, 2(3).

15 Ansori, A. G. (2009). Lembaga Kenotariatan Indonesia (Perspektif Hukum dan Etika). Yogyakarta: UII Press. h. 123.

16 Ibid.

17 Ibid. h. 62.
} 
Selain adanya hubungan yang sifatnya horizontal, terdapat pula hubungan vertikal. Hubungan vertikal yang dimaksud ialah hubungan notaris dengan Tuhan Yang Maha Esa. Hubungan ini merupakan hubungan personal vertikal dimana notaris memiki rasa tanggung jawab serta rasa takut terhadap Tuhan Yang Maha Esa yang notaris sendiri percayai. Hubungan yang sifatnya vertikal ini adalah inti dari hubungan yang sifatnya horizontal. Hubungan yang bersifat horzonal yang dimaksud ialah hubungan sesama manusia yang berlandaskan kepercayaan kepada Tuhan Yang Maha Esa.

Pada hakikatnya, etika profesi adalah wujud dari sikap etis notaris. Hal ini menjadi bagian dari konstituen dari suatu perilaku hidup dalam menjalankan suatu kehidupan sebagai individu yang berprofesi sebagai notaris. Akhlak notaris itu sendirilah yang menentukan sikap patuh atau tidaknya orang itu. Notaris dalam memikul kewenanganya dalam hal ini berkedudukan sebagai pejabat umum tentu kebanyakan orang-orang awam tidak bisa menilainya. Oleh karena itu, seorang notaris perlu mempunyai suatu pedoman yang obyektif dan konkrit bagi perilaku dirinya pada saat mengemban wewenangnya. Pedoman itulah yang dinyatakan dalam segenap kaidah atau bisa juga disebut norma tingkah laku yang menjadi patokan sebagai panduan yang wajib ditaati yang disebut kode etik profesi yang dalam hal ini bisa berbentuk tersurat ataupun tersirat.

Sebenarnya setiap anggota perkumpulan dari notaris atau I.N.I serta juga anggota masyarakat bisa melakukan kontrol terhadap profesi notaris melalui rumusan yang ada di dalam kode etik notaris. Orang-Orang yang tergabung dalam perkumpulan dan anggota masyarakat dapat menilai apakah seorang notaris itu sudah atau belum, sesuai atau tidak sesuai dengan kode etik profesi notaris dalam bertindak sesuai wewenangnya sebagai pejabat umum termasuk juga mengenai kewajiban dan tanggung jawabnya. Salah satu fungsi kode etik profesi notaris ialah untuk mencegah konflik dan kesalah pahaman yang kemungkinan bisa terjadi. Oleh sebab itu, guna upaya supremasi kode etik notaris, sangat diperlukan adanya integritas dan komitmen yang sangat kuat demi terpeliharanya kehormatan dan citra profesi notaris.

Seorang notaris yang patuh terhadap kode etik notaris tentu akan berusaha sebisa mungkin menerapkan ketentuan-ketentuan yang ada pada kode etik notaris, baik dari makna yang tersurat maupun yang tersirat. Seorang notaris yang bangga akan profesinya, tentu akan senantiasa menjaga hubungan baik antara dirinya dengan Tuhan Yang Maha Esa, sesama manusia, dan juga alam lingkungan. Seorang notaris yang menjaga hubungan baik dengan Tuhan Yang Maha Esa sebagai contoh ialah senantiasa berdo'a kepada Tuhan Yang Maha Esa yang ia percayai, bersabar dalam menghadapi masalah, serta mawas diri. Seorang notaris yang menjaga hubungan baik antar sesama manusia, sebagai contohnya ialah senantiasa berkata jujur, selalu murah senyum dan berkata-kata yang sopan dan mudah dimengerti dengan orang-orang disekitarnya terutama jika berhadapan dengan klien yang hendak menggunakan jasanya. Sedangkan seorang notaris yang menjaga baik hubungan dirinya dengan alam lingkungan sebagai contohnya ialah melakukan harmonisasi tempat tinggal dan kantornya terhadap alam.

\subsection{Sistem Administrasi dan Tata Kelola Kantor Notaris}

Kesuksesan notaris tidak bisa diperhatikan hanya dengan berapa banyak ia membuat akta, akan tetapi juga dari kemahirannya dalam memanajemen administrasi di kantor tempat ia bekerja. Keadaan dimana akta yang dibuat cukup banyak namun tidak disertai dengan sistem administrasi yang baik maka akan menjadi suatu 
problematika yang serius di kemudian hari. Oleh karena hal seperti itu, maka seorang notaris dan/atau calon notaris wajib mengetahui, mempelajari, serta juga memperhatikan bagaimana sistem administrasi yang baik agar kelak dapat terhindar dari masalah bila ia menjalankan jabatannya sebagai seorang notaris.

Secara umum, administrasi memiliki terjemahan segenap proses penataan dan pengelolaan partisipasi beberapa orang yang mendayagunakan fasilitas-fasilitas dan ketersediaan perlengkapan-perlengkapan guna efisiensi pencapaian suatu tujuan dari instansi. ${ }^{18}$ Kata administrasi sendiri mempunyai dua arti. Arti secara luas maupun secara sempit. Pemahaman administrasi secara luas dapat diartikan sebagai segala sesuatu yang menjadi bagian dari berproses suatu kerja sama antara beberapa orang demi mencapai tujuan bersama dengan cara memanfaatkan segala sesuatu sarana dan prasarana demi optimalitas apa kegiatan yang mereka lakukan. Sedangkan pemahaman administrasi dalam artiannya sempit ialah aktiviats-aktivitas yang berupa pencatatan, penyuratan, pengetikan, dan pembukuan yang sederhana, serta kegiatan-kegiatan lain yang sifatnya teknis dalam kegiatan ketata usahaan. ${ }^{19}$ Sehingga dari pengertian ini, dapat ditarik suatu kesimpulan bahwa definisi administrasi tersebut dapat memberikan pengetahuan mengenai tiga hal penting yang diantaranya ialah:

1. Administrasi menggambarkan wujud kesenian. Tindakan tertentu yang sifatnya situasional juga kondisional diperlukan administrasi dalam pengertiannya sebagai seni. Demikian karena administrasi selalu berkaitan dengan keadaan, realita, dan tempat, serta waktu;

2. Administrasi mengandung unsur-unsur terntentu. Unsur-unsur tertentu tersebut diantaranya ialah: terkandung beberapa orang, antar orang-orang tersebut terjalinnya aliansi yang sifatnya saling mengawasi dan mengingatkan dalam lingkup formal, adanya keharusan yang diemban, memiliki tujuan tertentu, serta adanya kelengkapannya;

3. Administrasi terlahirkan seirama dengan kelahiran peradaban umat manusia. Fungsi dari kelahiran administrasi itu berfungsi tercapainya tujuan aliansi.

Selain itu, ada beberapa ahli juga mengeluarkan pendapat mengenai definisi administrasi. Beberapa ahli tersebut diantaranya George R. Terry, Arthur Grager, Sondang P. Siagian, Ulbert, dan Willam Lefffingwell dan Edwin Robinson. George R. Terry memberikan pemahamannya mengenai administrasi. Menurut beliau seperti yang penulis pahami, administrasi ialah kegiatan-kegiatan yang berisikan rencana, kendali, dan pengorganisasian suatu pekerjaan yang ada di dalam kantor serta pergerakan secara keseluruhan untuk mencapai tujuan yang ditentukan sebelumnya. Sedangkan Arthur Grager berpendapat sebagaimana pemahaman penulis bahwa administrasi ialah keseluruhan manfaat mengenai hal-hal yang berkaitan dengan komunikasi dan pelayanan dalam organisasi. Hal senada juga diungkapkan oleh Sondang P. Siagian yang memberikan pendapat seperti yang penulis pahami bahwa administrasi adalah dua individu atau lebih yang terikat dalam proses kerja sama yang berlandaskan pemikiran rasionalitas yang sudah ditentukan guna mencapai tujuan yang telah ditentukan sebelumnya. Sedangkan Ulbert juga berpendapat mengenai pengertian administrasi yang menurut beliau seperti yang penulis pahami adalah dalam penjabarannya secara luas, administrasi merupakan kegiatan menyusun dan mencatat data atau suatu informasi tertentu yang kesemuanya dilakukan secara sistematis baik

\footnotetext{
18 Arif, S. N., Wanda, A. P., \& Masudi, A. (2013). Aplikasi Administrasi Perpustakaan Berbasis Web SMK Swasta Brigjend Katamso Medan. Jurnal SAINTIKOM Vol, 12(1). 19 Ibid.
} 
dari segi internal maupun ekternal yang kesemuanya itu mempunyai tujuan untuk memberikan keterangan dan kemudahan untuk mendapatkanya kembali secara sebagian atau semuanya. Sedangkan jabaran administrasi dalam katagori sempit dapat pula diartikan sebagai kegiatan tata usaha. Willam Lefffingwell dan Edwin Robinson mengutarakan pendapat beliau mengenai definisi administrasi sebagaimana yang penulis pahami bahwa administrasi adalah bagian-bagian dari ilmu managemen yang kesemuanya berkenaan dengan tata laksana terhadap pekerjaan di dalam kantor yang dilaksanakan secara tepat guna dan tepat sasaran. Sehingga dari beberapa definisi mengenai administrasi ini, dapat ditarik suatu kesimpulan dari penulis bahwasanya administrasi adalah "sebuah bentuk gerak untuk pekerjaan dan aktivitas yang berhubungan dengan pengaturan kebijakan agar dapat mencapai target dan/atau tujuan suatu organisasi. Sehingga administrasi dapat dikatakan mempunyai peranan yang sangat teramat krusial dalam semua aktivitas sebuah organisasi." 20

Kata "kantor" dapat ditinjau dari artian statis yang maksudnya ialah keadaan fisik berupa bangunan yang berfungsi sebagai sarana atau tempat yang dapat berupa rumah toko (ruko), rumah, dan gedung, atau hanya suatu ruangan dimana kegiatan ketata usahaan dilakukan. Namun dalam artian yang dinamis, kantor dapat diartikan sebagai suatu organisasi yang di dalamnya terdapat penugasan, susunan keanggotaan, tanggung jawab, kewajiban, dan hak, serta terdapat kewenangan dari setiap anggota organisasi yang bersangkutan. Kamus Besar Bahasa Indonesia (selanjutnya disebut $\mathrm{KBBI})$ juga memberikan definisi mengenai kantor yang artinya ialah "sebuah balai (ruang, gedung, dan rumah) tempat yang digunakan untuk mengurus suatu pekerjaan (suatu instansi atau perusahaan); tempat bekerja." 21

Dari penjabaran di atas, dapat ditarik suatu kesimpulan mengenai administrasi kantor notaris. Suatu rentetan kegiatan yang menyeluruh mengenai aktivitas-aktivitas ketata usahaan dan manajerial dari adanya kantor notaris sebagai maksud tertentu yang telah direncanakan disebut administrasi kantor notaris. Ada beberapa hal yang terbilang wajib untuk ditinjau supaya pelaksanaan kegiatan terlaksana secara optimal pada kantor notaris. Hal yang ditinjau itu meliputi: kantor, inventaris (peralatan) kantor, karyawan, pendokumentasian arsip.

Sudah tidak dapat dipungkiri lagi bahwasanya kantor notaris yang keadaanya baik, maka secara otomatis klien akan terpikat dengan daya tarik dari kantor tersebut. Bila suatu kantor notaris itu baik, maka akan terkesan baik pula notarisnya. Baik buruknya kantor notaris tidak ditinjau dari besar, luas, ataupun kemegahnnya. Kantor notaris yang baik ialah kantor yang semua elemen-elemennya bertempat sebagaimana fungsinya. Ruangan-ruangan yang ada di dalam kantor tertata rapi, kondisi di dalam dan di sekitar kantor bersih dan anggun. Kesan yang nyaman dan terpercaya tentu bisa di dapat jika semua itu sudah diakukan. Penataan ruangan-ruangan dengan baik tentu mampu memberikan perasaan senang dan nyaman terutama bagi karyawan yang telah bekerja di kantor tersebut serta klien yang datang ke kantor tersebut. Berikut ialah halhal yang hendaknya diperhatikan sebagai upaya untuk menjadikan keadaan kantor notaris menjadi baik:

20 Admin. (2019). Pengertian Administrasi Secara Umum, Tujuan, Fungsi, dan Ciri-Ciri Administrasi. Available at:: https://www.maxmanroe.com/vid/manajemen/pengertianadministrasi.html. Diakses 02 Juli 2019

21 KBBI. (2016). Kamus Besar Bahasa Indonesia (KBBI). (Online). Available at: http://kbbi.web.id/pusat. (Diakses 02 Juli 2019) 
1. Suatu kantor notaris, hendaknya memiliki minimal ruang untuk kerja bagi notaris, ruang untuk penyimpanan arsip dan protokol, ruang untuk melakukan rapat, dan ruang untuk karyawan. Hal-hal tersebut ditata sedemikian rupa dan sebaik mungkin. Sebagai contoh, ruang yang digunakan untuk rapat yang notabennya tenang dan nyaman seharusnya tidak diganggu dengan suara-suara mesin pencetak dari karyawan yang sedang mencetak akta atau surat-surat lainnya;

2. Berusaha sebisa mungkin agar setiap ruangan mendapat penerangan baik itu dari sinar matahari atau penerangan dari sinar lampu yang baik karena hal tersebut mampu memberikan nilai positif untuk produtivitas, mencegah terjadinya kesalahan yang mungkin terjadi serta mampu meningkatkan kewibawaan kantor;

3. Estestika atau keindahan kantor dan pemilihan jenis cat untuk dinding ruangan juga dapat memberikan kesan yang sifatnya mendalam serta juga dapat memberikan nilai maksimal terhadap semangat kerja;

4. Jika keuangan mencukupi, maka pada ruangan kantor lebih baik dipasangi pengatur suhu ruangan (air conditioner) atau minimal kipas angin karena hal ini sanggup menigkatkan kemampuan produksi, pegawai merasa bahagia, sepirit produksi yang tentu bertambah, dan perasaan yang elegan serta nyaman akan didapatkan bagi siapapun yang berkunjung ke kantor tersebut.

Fasilitas lain yang juga harus mendapatkan perhatian ialah inventaris (peralatan) kantor. Kecepatan dan baik buruk hasil kerja karyawan juga tak lepas dari pengaruh peralatan kantor yang mumpuni dan sesuai dengan harapan. Dalam kantor notaris, minimal tersedia fasilitas seperti diantaranya adalah: lemari penyimpanan, mesin ketik, meja dan kursi, komputer dan printer, dan jaringan internet serta TV jika memungkinkan. Untuk pemilihan perlengkapan inventaris kantor notaris, sudut pandang yang mungkin bisa menjadi pertimbangan adalah hal-hal yang meliputi: apakah alat-alat tersebut dapat digunakan oleh pegawai dan apakah alat-alat tersebut memenuhi apa saja kebutuhan-kebutuhan pegawai, kemudian apakah alat-alat tersebut membantu jenis pekerjaan pegawai dan apakah alat-alat tersebut dapat membantu pegawai untuk mampu menyelesaikan pekerjaanya, kemudian yang tidak kalah penting ialah bagaimana jumlah dan esensi pekerjaan, dan yang terakhir adalah ketahanan penggunaan, harga, dan layanan purna jual serta keasriannya.

Karyawan diperlukan oleh seorang notaris guna membantu pekerjaanya untuk menyusun akta-akta maupun dalam melakukan administrasi terhadap akta, surat, dan dokumen-dokumen lainnya. Hal ini karena notaris bertugas membuat akta-akta yang mewakilkan wujud dari dokumen (arsip) negara yang rudiment dan wajib dijaga dengan benar. Tidak sedikit aturan-aturan yang wajib di patuhi oleh notaris. Karyawan notaris juga harus mengetahui dan sangat paham akan kewajiban dan tanggung jawabnya. Karyawan notaris harus mempunyai sikap pasti atas perbuatannya, memahami apa saja yang dilarang untuk segala tingkah lakunya yang tidak sesuai dengan nilai-nilai, maupun apa saja yang memang harus dihindari. Di samping itu, karyawan notaris hendaknya berkriteria: teliti, jujur, mempunyai pengetahuan yang luas, serta berdedikasi tinggi.

Hal yang terkhir adalah pendokumentasian atau sering disebut tata kearsipan. Dokumen atau arsip itu sendiri definisinya menurut Undang-Undang Nomor 43 Tahun 2009 tentang Kearsipan (selanjutnya disebut UUK) khususnya pada Pasal 1 angka 2 adalah "Arsip adalah rekaman kegiatan atau peristiwa dalam berbagai bentuk dan media sesuai dengan perkembangan teknologi informasi dan komunikasi yang dibuat 
dan diterima oleh lembaga negara, pemerintahan daerah, lembaga pendidikan, perusahaan, organisasi politik, organisasi kemasyarakatan, dan perseorangan dalam pelaksanaan kehidupan bermasyarakat, berbangsa, dan bernegara." 22 Tata kearsipan juga memiliki maksud yaitu mekanisme penyimpanan serta pengaturan dokumen secara sistematis dan rapi. Hal ini ditujukan agar arsip yang memang dibutuhkan dapat ditemukan dan diambil dengan mudah serta dapat dikembalikan lagi ke tempatnya dengan mudah pula. Prihal penyimpanan akta-akta, tidak boleh dilakukan dengan ngawur karena benda tersebut wujud dari dokumen (arsip) negara yang kapasitasnya dapat di katakan darurat yang artinya wajib mendapatkan perlakuan dengan sangat baik dan dengan rasa pertanggung jawaban dengan sepenuh hati.

\section{Kesimpulan}

Dalam hal menjalankan profesinya, seorang notaris tentu terikat dengan norma dan nilai yang menjadi barometer moralitasnya apakah ia sudah bertindak secara etis atau belum. Jika ditinjau dari segi filosofis, memang sejauh ini tidak ada barometer yang berlaku secara menyeluruh dan universal sebagai tolak ukur perilaku etis profesi notaris. Namun meskipun demikian, nilai-nilai yang ada saat ini sudah dapat diuraikan sebagai prinsip-prinsip yang berlaku dan tentu dapat diterapkan pada situasi dan kondisi pada suatu waktu tertentu. Dalam melayani klien, hendaknya seorang notaris harus bersikap ramah, murah senyum, menggunakan kosa kata yang tepat dan pas, berbahasa yang mudah dipahami dan dimengerti, sopan dan santun, tidak mudah tersinggung dan emosional, sabar, dan bijaksana sehingga terwujudlah suatu kondisi dan situasi yang aman, nyaman, dan kondusif yang tentu dengan demikian tercapainya rasa kepercayaan klien terhadap notaris itu sendiri. Kode etik notaris ialah tingkatan yang lebih faktual dan juga konkrit mengenai perilaku etis seorang notaris. Untuk menjaga supremasi kode etik notaris tersebut, maka diperlukannya integritas dan komitmen yang sangat tinggi demi terwujudnya moralitas positif terhadap profesi notaris serta untuk menjaga kewibawaan, reputasi, dan kehormatan notaris. Hal itu harus dilakukan secara konstan agar terwujudnya standar perilaku etis terhadap profesi notaris sehingga terciptalah suatu arah berperilaku dari rumusan kode etik notaris serta pemaknaan juga penghayatan secara konteks mengenai penerapan kode etik notaris. Kode etik notaris yang merupakan satu-satunya tolak ukur hendaknya selalu disesuaikan dengan perkembangan zaman dan kemajuan teknologi agar dapat di terapkan baik ketentuan yang tersurat maupun yang tersirat di dalam kode etik tersebut serta tercapainya suatu simbiosis mutualisme antara para pihak.

Keberhasilan seorang notaris, selain dipengaruhi oleh moralitasnya dalam memberikan pelayanan kepada masyarakat juga dipengaruhi oleh sistem administrasi dan tata kelola kantornya. Sangat penting bagi seorang notaris dalam menjaga ketertiban administrasi kantornya dan memperhatikan tata kelola kantornya dengan baik. Karena sebagaimana fungsi notaris sebagai pejabat umum, salah satunya ialah membuat dokumen (arsip) negara yang tentu sangat penting, sehingga dokumen atau arsip negara tersebut harus dibuat dan dijaga sebaik mungkin agar tidak terjadi konflik serta kerusakan atau hal-hal lain yang memang tidak diinginkan yang dapat merugikan pihak-pihak yang terkait.

22 Wirawanty, F. (2014). Tata Kelola Penyimpanan Arsip dalam Upaya Meningkatkan Efisiensi Penemuan Kembali Arsip di Kantor Perpustakaan Umum dan Arsip Kabupaten Pamekasan. Jurnal Administrasi Perkantoran (JPAP), 2(2). 


\section{Ucapan terima Kasih (Acknowledgments)}

Penulis menghaturkan terima kasih yang tak terhingga kepada Tuhan Yang Maha Esa, Allah Subhanahu Wa Ta'ala karena berkat ridha dan karunia Beliau, penulis masih diberi kesempatan untuk menulis Jurnal ini. Terimakasih juga penulis sampaikan kepada Nabi Muhammad Shalallaahu 'Alayhi Wasallam karena semangat, nasihat, dan perilaku beliau menjadi suri tauladan penulis. Sampaian terimakasih juga penulis tujukan kepada Bapak dan Ibu pengajar serta staf-staf yang bertugas karena penulis selama ini banyak memetik ilmu dari proses belajar dan mengajar, nasihat-nasihat serta kemudahan-kemudahan dari Bapak dan Ibu pengajar dan staf-staf di Program Studi Magister Kenotariatan Fakultas Hukum Universitas Udayana.

\section{Daftar Pustaka / Daftar Referensi}

Online/World Wide Web:

Admi. (2019). Pengertian Administrasi Secara Umum, Tujuan, Fungsi, dan Ciri-Ciri Administrasi. Available at: https://www.maxmanroe.com/vid/manajemen/ pengertian-administrasi.html. Diakses 02 Juli 2019

\section{Website Resmi:}

KBBI. (2016). Kamus Besar Bahasa Indonesia (KBBI). (Online). Available at: http://kbbi.web.id/pusat. (Diakses 02 Juli 2019)

\section{Buku / Literatur:}

Ansori, A. G. (2009). Lembaga Kenotariatan Indonesia (Perspektif Hukum dan Etika). Yogyakarta: UII Press

Bertens, K. (2002). Etika. Jakarta: PT. Gramedia Pustaka Utama

Soekanto, S., \& Mamuji, S. (2009). Penelitian Hukum Normatif Suatu Tinjauan Singkat. Jakarta: PT. Raja Grafindo Persada

Rusli, H. (2006). "Metode Penelitian Hukum Normatif: Bagaimana?". Tanggerang: Law Review Fakultas Hukum Universitas Pelita Harapan, Volume V No. 3 Tahun 2006

Muchsin. (2004). Ikhtisar Materi Pokok Filsafat Hukum. Jakarta: STIH ‘IBLAM”

Marzuki, P. M. (2009). Penelitian Hukum. Jakarta: Kencana Prenada Media Group

\section{Jurnal:}

Arif, S. N., Wanda, A. P., \& Masudi, A. (2013). Aplikasi Administrasi Perpustakaan Berbasis Web SMK Swasta Brigjend Katamso Medan. Jurnal SAINTIKOM Vol, 12(1).

Barus, Z. (2013). Analisis Filosofis Tentang Peta Konseptual Penelitian Hukum Normatif dan Penelitian Hukum Sosiologis. Jurnal Dinamika Hukum, 13(2), 307-318.

Dinaryanti, A. R. (2013). Tinjauan Yuridis Legalisasi Akta Di Bawah Tangan Oleh Notaris. Legal Opinion, 1(3).

Hayatdian, H. D. (2013). Kajian Hukum Surat Kuasa Dibawah Tangan Sebagai Dasar Pembuatan Akta Jaminan Fidusia. Jurnal Hukum Unsrat, 1(1), 120-135. 
Jumiati, I. E. (2012). Dimensi etika dalam pelayanan publik: arti penting, dilema dan implikasinya bagi pelayanan publik di Indonesia. Jurnal Administrasi Publik, 3(1), 3243.

Laurensius Arliman, S. (2018). Peranan Metodologi Penelitian Hukum di Dalam Perkembangan Ilmu Hukum di Indonesia. Jurnal Soumatera Law Review, 1(1).

Supriyanta. (2013). Kajian Filosofis Terhadap Standar Perilaku Notaris. Jurnal Yustisia, 2(3).

Wibawa, P. G. S., Windari, R. A., Sudiatmaka, K., \& Si, M. (2019). PERLINDUNGAN HUKUM BAGI NOTARIS TERHADAP PEMANGGILAN NOTARIS OLEH PENEGAK HUKUM DALAM PROSES PRADILAN DI TINJAU DARI KETENTUAN PASAL 66 UNDANG-UNDANG NOMOR 2 TAHUN 2014. Jurnal Komunitas Yustisia, 2(1).

Wirawanty, F. (2014). Tata Kelola Penyimpanan Arsip dalam Upaya Meningkatkan Efisiensi Penemuan Kembali Arsip di Kantor Perpustakaan Umum dan Arsip Kabupaten Pamekasan. Jurnal Administrasi Perkantoran (JPAP), 2(2).

Yuhertiana, I. (2016). Etika, Organisasi dan Kepatuhan Wajib Pajak. Jurnal Akuntansi Multiparadigma, 7(1), 131-141.

\section{Peraturan Perundang-Undangan:}

Undang-Undang Nomor 30 Tahun 2004 tentang Jabatan Notaris (Lembaran Negara Republik Indonesia Tahun 2004 Nomor 117, Tambahan Lembaran Negara Republik Indonesia Nomor 4432)

Undang-Undang Nomor 43 Tahun 2009 tentang Kearsipan (Lembaran Negara Republik Indonesia Tahun 2009 Nomor 152, Tambahan Lembaran negara Republik Indonesia Nomor 5071)

Undang-Undang Nomor 2 Tahun 2014 tentang Perubahan Atas Undang-Undang Nomor 30 Tahun 2004 tentang Jabatan Notaris (Lembaran Negara Republik Indonesia Tahun 2014 Nomor 3, Tambahan Lembaran Negara Republik Indonesia Nomor 5491)

Kitab Undang-Undang Hukum Perdata (KUHPer)

Perubahan Kode Etik Notaris Kongres Luar Biasa Ikatan Notaris Indonesia Banten, 2930 Mei 2015 